\title{
Aquatic oligochaeta (Annelida: Clitellata) in extractive reserve Lake Cuniã, Western Brazilian Amazon
}

\author{
Diego Ferreira Gomes ${ }^{1 *}$, Nathalie Aparecida Oliveira Sanches ${ }^{1}$, Lucas Henrique Sahm ${ }^{1}$ \& \\ Guilherme Rossi Gorni ${ }^{1}$ \\ ${ }^{1}$ Universidade de Araraquara - UNIARA, Programa de Pós-graduação em Desenvolvimento Territorial e Meio \\ Ambiente, Rua Carlos Gomes, CEP: 14801-340, Araraquara, SP, Brazil \\ *Corresponding author: Diego Ferreira Gomes e-mail: diego.frgomes@gmail.com
}

GOMES, D.F., SANCHES, N.A.O., SAHM, L.H., GORNI, G. Aquatic oligochaeta (Annelida: Clitellata) in extractive reserve Lake Cuniã, Western Brazilian Amazon. Biota Neotropica. 17(1): e20160232. http://dx.doi.org/10.1590/16760611-BN-2016-0232

\begin{abstract}
Oligochaeta is one of the most common and abundant taxon in continental aquatic fauna. However, knowledge of their distribution in Brazilian ecosystems is still incomplete and fragmented. Thus, the aim of this study was to develop an inventory of aquatic oligochaetes in the Extractive Reserve of Lake Cuniã in the State of Rondônia, Brazil. Collections of data were performed during the dry (August 2015) and rainy seasons (February 2016). The sediment samples were collected near the lakeside region using the kick sampling method and a kick-net sampler (mesh size of $0.25 \mathrm{~mm}$ ). This paper provides a catalog with 12 taxon from a total of 383 specimens, distributed into two families: Naididae (95.08\%) and Opistocystidae (4.92\%). The Pristininae subfamily was the most significant (85.68\%), followed by subfamilies: Naidinae $(8.36 \%)$, Tubificinae $(0.52 \%)$ and Rhyacondrilinae $(0.52 \%)$. In addition, some species such as Allonais inaequalis, Aulophorus furcatus, Dero nivea, Pristina synclites, Pristina menoni and Opistocysta serrata, were recorded for the first time in the Brazilian Amazon region. Therefore, the results of this study contribute to increase knowledge on the distribution of the Oligochaeta class in Brazil, particularly in the North of the country, which is so extensive and rich in water resources, but not extensively studied.
\end{abstract}

Keywords: Biodiversity, aquatic macroinvertebrates, Amazon region, Microdrili.

\section{Oligoquetos aquáticos (Annelida: Clitellata) na reserva extrativista Lago do Cuniã, Amazônia Ocidental Brasileira}

\begin{abstract}
Resumo: Oligochaeta é um dos táxons mais comuns e abundantes na fauna aquática continental. No entanto, o conhecimento da sua distribuição nos ecossistemas brasileiros ainda é incompleto e fragmentado. Assim, o objetivo deste estudo foi desenvolver um inventário de oligoquetos aquáticos na Reserva Extrativista do Lago Cuniã no estado de Rondônia, Brasil. Foram realizadas duas coletas, cobrindo o período seco (agosto 2015) e chuvoso (fevereiro 2016). As amostras de sedimento foram coletadas perto da região marginal do lago pelo método de amostragem Kick sampling usando um amostrador Kick-net (malha de $0,25 \mathrm{~mm}$ ). Nós catalogamos 12 táxons do total de 383 espécimes, distribuídos em duas famílias: Naididae (95,08\%) e Opistocystidae (4,92\%). A subfamília Pristininae foi a mais significativa (85,68\%), seguida das subfamílias: Naidinae (8,36\%), Tubificinae (0,52\%) e Rhyacondrilinae (0,52\%). Além disso, algumas espécies, como Allonais inaequalis, Aulophorus furcatus, Dero nivea, Pristina synclites, Pristina menoni e Opistocysta serrata, tiveram o primeiro registro na Amazônia brasileira. Assim, os resultados deste estudo contribuem para aumentar o conhecimento da distribuição da classe Oligochaeta no Brasil, particularmente no Norte do país, que é tão extenso e rico em recursos hídricos, porém pouco estudado.
\end{abstract}

Palavras-chave: Biodiversidade, macroinvertebrados aquáticos, região amazônica, Microdrili.

\section{Introduction}

Even though tropical regions are considered the most important in biodiversity, the biotas of these areas are rarely explored and still possess many undescribed species (Lewinsohn \& Prado, 2005). In this context, Brazilian invertebrate diversity remains largely unknown, mainly because some groups receive more attention than others (Hortal et al. 2015) and the difficulties in taxonomic identification discourage the development of new studies. This results in fragmented and scarce information on the invertebrate fauna (Magurran, 2011), especially in continental aquatic ecosystems, where the information about this group is even more incomplete (Agostinho et al. 2005). 
Aquatic Oligochaeta worms are one of the most abundant organisms in continental aquatic fauna and can be found in sediments, in water columns or associated to other organisms such as molluscs (Gorni \& Alves, 2006), aquatic macrophytes (Alves \& Gorni, 2007), insect larvae (Corbi et al. 2004), bryophytes (Gorni \& Alves, 2007), sponges (Gorni \& Alves, 2008a) and amphibians (Oda et al., 2015). It is important to highlight that these organisms are important for organic matter cycling of freshwater ecosystems, bioturbation processes, biomonitoring research, aquatic ecotoxicology and test organisms (Chapman, 2001, Corbi et al. 2015).

However, despite the importance of Oligochaeta in the dynamics of aquatic environments, there have been few scientific studies focused on registering these organisms in Brazilian ecosystems (Gorni \& Alves, 2008b). Consequently, Christofferson (2010) affirms that studies on oligochaetes in South America are a pioneer phase.

In the Brazilian Amazon, Du Bois- Reymond Marcus (1947; 1949a; 1949b) and Marcus $(1942 ; 1943 ; 1944)$ were the first researchers to register many of the species known in scientific literature. Eventually, some species of Oligochaeta were recorded by Imler (1989) and Collado \& Schmelz $(2000 ; 2001)$. Similarly, organisms of this class have been identified in the Ecuadorian Amazon (Turcotte \& Harper, 1982) and Colombian Amazon (Carvajal et al., 2009). However, studies on the Amazon aquatic macrofauna have not evolved to present specific levels of species identification (Cleto-Filho \& Walker, 2001, Lopes et al. 2011, Aviz et al. 2012).

This study provides a checklist of aquatic oligochaete in The Extractive Reserve of Lake Cuniã - Rondônia, in the Western Brazilian Amazon, and proposes a catalog of the local species found and their ecological information.

\section{Materials and Methods}

\section{Area of Study}

This study was conducted in the Extractive Reserve of Lake Cuniã (Figure 1), located about 130 kilometers from Porto Velho, on the left bank of the lower Madeira River. With an area of approximately 55.850 hectares, the Reserve has two distinct areas. The first is formed by a piece of land that has a diverse environment with high biodiversity and the second is a floodplain area with seasonal water flow throughout the year. The wet season occurs from November to April and the dry season from May to October.

\section{Data collection}

Two expeditions were conducted, covering the dry season (August 2015) and the rainy season (February 2016). Sediment samples were collected on seven sites that are near the lakeside region and have floodplain characteristics: S1 $\left(08^{\circ} 20^{\prime} 15.5^{\prime \prime} \mathrm{S} 63^{\circ} 31^{\prime} 38.5^{\prime \prime} \mathrm{W}\right), \mathrm{S} 2$ (08 20'08.9” S

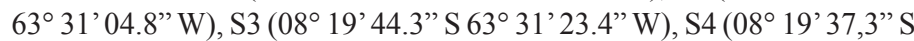

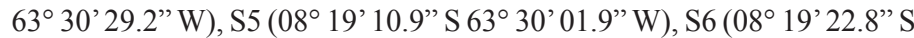
$\left.63^{\circ} 29^{\prime} 29.5^{\prime \prime} \mathrm{W}\right)$ and S7 ( $\left.08^{\circ} 18^{\prime} 40.0^{\prime \prime} \mathrm{S} 63^{\circ} 29^{\prime} 19.0^{\prime \prime} \mathrm{W}\right)$. These sites are periodically inundated by the overflow of the lake and present a specific diversity of morphologically adapted vegetation that tolerate this seasonal flood pulse (Martinez \& Le Toan, 2006). Furthermore, these sites are organically rich, due to the large amounts of organic substances, originated from local vegetation, that are dissolved in flood water (Junk, 1997). Sample collection was done using the kick sampling method and a kick-net sampler (mesh size of $0.25 \mathrm{~mm}$ ) as described by Alves et al. (2008) and Docile et al. (2016).

Samples were oxygenated with aquarium pumps to maintain the organisms living during the screening process. For organism selection, small portions of the samples were put into translucent trays containing water and subsequently fixed in 10\% formalin and preserved in $70 \%$ alcohol (Alves \& Gorni, 2007). Semi-permanent slides were prepared and the taxonomic criteria adopted by Righi (1984) and Brinkhurst \& Marchese (1989) were followed in order to identify Oligochaeta. The identified specimens were deposited in the Zoological Collection of the University of Araraquara (UNIARA). Water temperature, dissolved oxygen, $\mathrm{pH}$ and electrical conductivity were measured in each site of the lake with a multiparameter sensor (YSI 5560). The concentrations of organic matter were determined

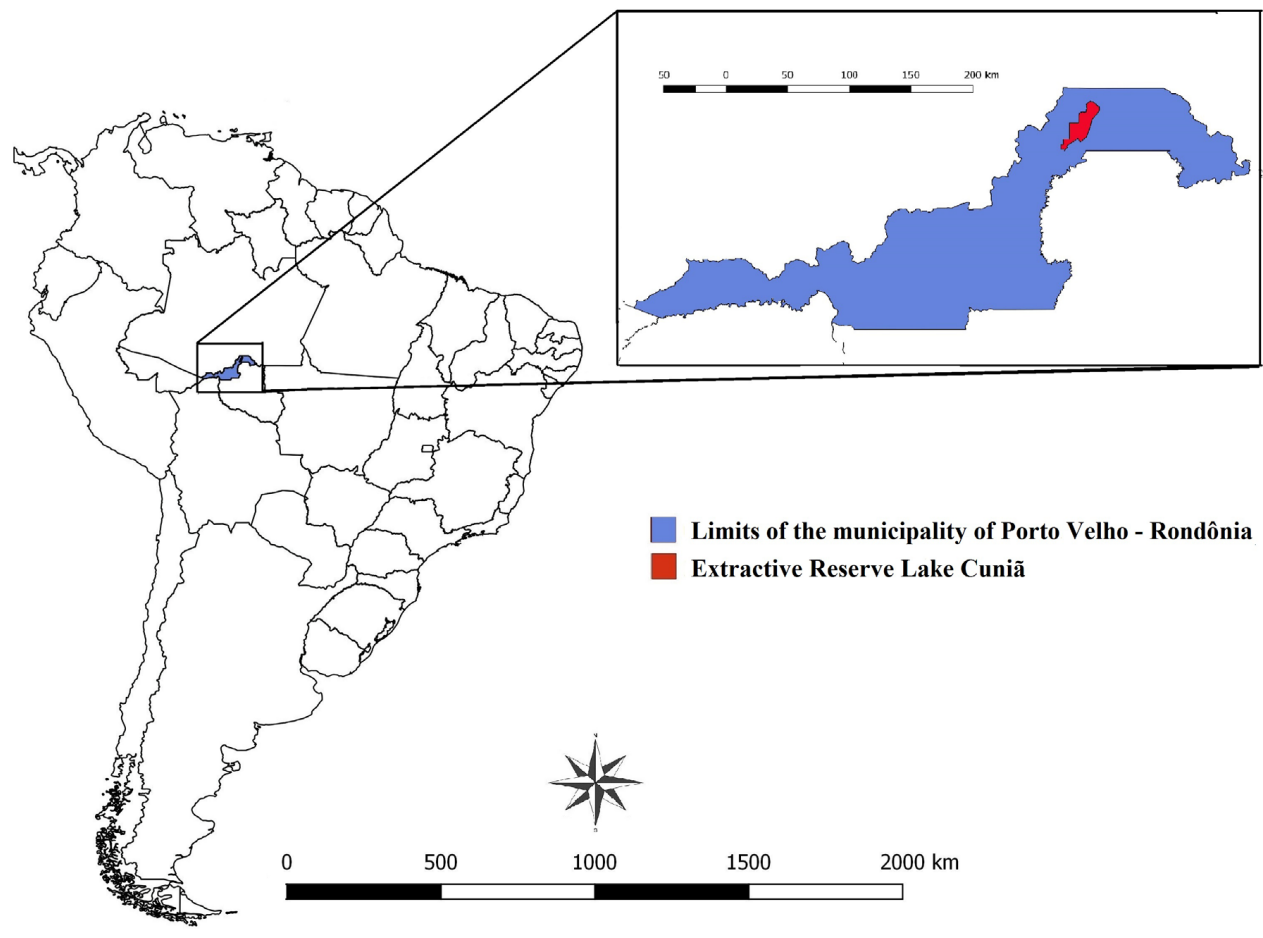

Figure 1. Location of Extractive Reserve Lake Cuniã in the state of Rondônia, Brazil. Source: Own author (2016) 
by mass loss. For this purpose, sediment samples were dried for 12 hours at $60{ }^{\circ} \mathrm{C}$ and then ignited at $550{ }^{\circ} \mathrm{C}$ for $5 \mathrm{~h}$, according to Maitland (1979).

Information on oligochaeta species in Brazil were searched for in the following databases: Scopus, Google Scholar, and Scielo, with no date filter. Papers by Marcus (1942, 1943, 1944) and Christoffersen (2007) were also consulted for obtaining additional data.

\section{Results}

The dissolved oxygen in the rainy season reached a maximum of $5.250 \mathrm{mg} / \mathrm{L}$ in S5, while the minimum for the dry season was $1.950 \mathrm{mg} / \mathrm{L}$ in S6. The oxygen concentration measured in the Cuniã Lake followed a pattern previously found by Almeida \& Melo (2009) in Amazon lakes. Temperature was high, electrical conductivity was low, especially during the dry season, and the $\mathrm{pH}$ was acid at all sites of the lake. Regarding organic matter, sites S6 and S7 presented the highest concentrations throughout the year and presented a small increase during the rainy season (Table 1).

This study provides a catalog with 12 taxa from a total of 383 specimens, distributed in two families: Naididae (95.08\%) and Opistocystidae (4.92\%). The subfamily Pristininae was the most significant ( $85.68 \%$ ), followed by subfamilies: Naidinae $(8.36 \%)$, Tubificinae $(0.52 \%)$ and Rhyacondrilinae $(0.52 \%)$ (Table 2$)$.
The Dero sp. species was only collected in dry season samples, but we were not able to properly count the number of gills, making it impossible to identify the species level. Similarly, the Bothrioneurum sp. species and immature tubificinae were not identified at more specific levels. Pristina sp.1 showed a different dorsal needle setae compared to the species already described in literature, and may be a new species of the genus.

\section{List and considerations about species}

\section{Allonais inaequalis (Stephenson, 1911) (Figure 2a)}

A species common in freshwater ecosystems of tropical and subtropical regions (Timm, 1999, Suriano-Affonso et al. 2011). In Brazil, it has been found in the State of São Paulo associated with other organisms such as gastropods (Gorni \& Alves, 2006), aquatic macrophytes (Alves \& Gorni, 2007), and sponges (Gorni \& Alves, 2008a). It has also been recorded in an urban stream by Alves et al. (2006).

\section{Aulophorus furcatus (Müller, 1774) (Figure 2b)}

A cosmopolitan species, characterized by the presence of gills and palps in the posterior region of its body (Brinkhurst \& Marchese, 1989). Its occurrence in Brazilian aquatic environments has been registered in the States of São Paulo, Paraná, Minas Gerais, Pernambuco and Rio

Table 1 - Mean and standard deviation of the environmental variables (measured in the dry season in August 2015 and rainy season in January 2016). W.T.: Water Temperature $\left({ }^{\circ} \mathrm{C}\right)$; E.C.: Electrical Conductivity $(\mu \mathrm{s} / \mathrm{cm})$; D.O.: Dissolved Oxygen $(\mathrm{mg} / \mathrm{L})$ and $\mathrm{pH}$; O.M.: Organic matter $(\%)$.

\begin{tabular}{|c|c|c|c|c|c|c|c|}
\hline \multicolumn{8}{|c|}{ Dry } \\
\hline & S1 & S2 & S3 & $\mathrm{S4}$ & S5 & S6 & S7 \\
\hline W.T $\left({ }^{\circ} \mathrm{C}\right)$ & $28.20(1.903)$ & $29.28(0.080)$ & $29.21(0.067)$ & $29.52(0.076)$ & $29.21(0.042)$ & $29.70(0.017)$ & $29.44(0.100)$ \\
\hline E. C. $(\mu \mathrm{s} / \mathrm{cm})$ & $10.00(0.000)$ & $10.00(0.000)$ & $11.00(0.000)$ & $26.33(0.577)$ & $19.00(0.000)$ & $41.33(0.577)$ & $25.00(0.000)$ \\
\hline D. O. (Mg/L) & $3.540(0.606)$ & $3.450(0.334)$ & $3.830(0.204)$ & $3.880(0.040)$ & $4.780(0.153)$ & $1.430(0.149)$ & $2.350(0.078)$ \\
\hline pH & $4.263(0.042)$ & $4.320(0.185)$ & $4.397(0.045)$ & $4.667(0.032)$ & $4.730(0.017)$ & $4.933(0.075)$ & $4.750(0.044)$ \\
\hline O.M (\%) & $8.6(7.6)$ & $10.3(7.6)$ & $9.5(1.3)$ & $19.8(6.8)$ & $5.7(3.1)$ & $19.4(10.6)$ & $15.1(2.4)$ \\
\hline \multicolumn{8}{|c|}{ Rainy } \\
\hline W. T. $\left({ }^{\circ} \mathrm{C}\right)$ & $29.10(0.091)$ & $29.23(0.031)$ & $29.27(0.070)$ & $28.91(0.119)$ & $29.11(0.292)$ & $30.27(0.363)$ & $29.70(0.605)$ \\
\hline E. C. $(\mu \mathrm{s} / \mathrm{cm})$ & $31.00(1.000)$ & $25.00(1.732)$ & $31.67(1.528)$ & $55.00(1.000)$ & $61.00(0.000)$ & $66.67(1.155)$ & $69.67(1.155)$ \\
\hline D. O. (Mg/L) & $4.030(0.085)$ & $4.60(0.254)$ & $4.90(0.023)$ & $4.170(0.178)$ & $5.250(0.131)$ & $1.950(0.116)$ & $2.840(0.055)$ \\
\hline pH & $4.883(0.055)$ & $4.817(0.072)$ & $4.937(0.059)$ & $5.060(0.040)$ & $5.187(0.050)$ & $5.317(0.075)$ & $5.400(0.026)$ \\
\hline O.M (\%) & $5.7(2.0)$ & $5.7(2.8)$ & $10.9(7.3)$ & $7.7(6.8)$ & $12.9(9.3)$ & $20.9(10.2)$ & $16.3(10.7)$ \\
\hline
\end{tabular}

Table 2: Oligoqueta taxa registered in the Extractive Reserve Lake Cuniã.

\begin{tabular}{|c|c|c|c|c|c|c|c|c|c|c|c|c|c|c|}
\hline \multirow{2}{*}{$\begin{array}{l}\text { Season } \\
\text { Sites }\end{array}$} & \multicolumn{7}{|c|}{ Dry } & \multicolumn{7}{|c|}{ Rainy } \\
\hline & S1 & S2 & S3 & S4 & S5 & S6 & S7 & S1 & $\mathbf{S 2}$ & S3 & S4 & S5 & S6 & S7 \\
\hline \multicolumn{15}{|l|}{ Naididae Family } \\
\hline \multicolumn{15}{|l|}{ Naidinae Subfamily } \\
\hline Allonais inaequalis & & & & & & & & & & & & & $\mathrm{x}$ & $\mathrm{x}$ \\
\hline Aulophorus furcatus & & $\mathrm{x}$ & & $\mathrm{x}$ & & & & & & & & & & \\
\hline Aulophorus costatus & & & & & & & & & & & & & & $\mathrm{x}$ \\
\hline Dero digitata & & & & & & & & $\mathrm{x}$ & & & & & & \\
\hline Dero nivea & & & & & & & & $\mathrm{x}$ & & $\mathrm{x}$ & & $\mathrm{x}$ & & \\
\hline Dero sp. & & & & $x$ & $\mathrm{x}$ & $\mathrm{x}$ & & & & & & & & \\
\hline \multicolumn{15}{|l|}{ Pristininae Subfamily } \\
\hline Pristina synclites & & $\mathrm{x}$ & & & & & & $\mathrm{x}$ & & & $\mathrm{x}$ & $\mathrm{x}$ & & $\mathrm{x}$ \\
\hline Pristina menoni & & & & & & & & & $\mathrm{x}$ & & & & & \\
\hline Pristina sp.1 & & & & & $\mathrm{x}$ & & & & & & & & & \\
\hline \multicolumn{15}{|l|}{ Tubificinae Subfamily } \\
\hline Immature Tubificinae & & & & & & $\mathrm{x}$ & & & & & & & & \\
\hline \multicolumn{15}{|c|}{ Rhyacodrilinae Subfamily } \\
\hline Bothrioneurum sp. & & & & $\mathrm{x}$ & & & & & & & & & & \\
\hline \multicolumn{15}{|l|}{ Opistocystidae Family } \\
\hline Opistocysta serrata & & & & & & & & $\mathrm{x}$ & & & $\mathrm{x}$ & & & \\
\hline
\end{tabular}



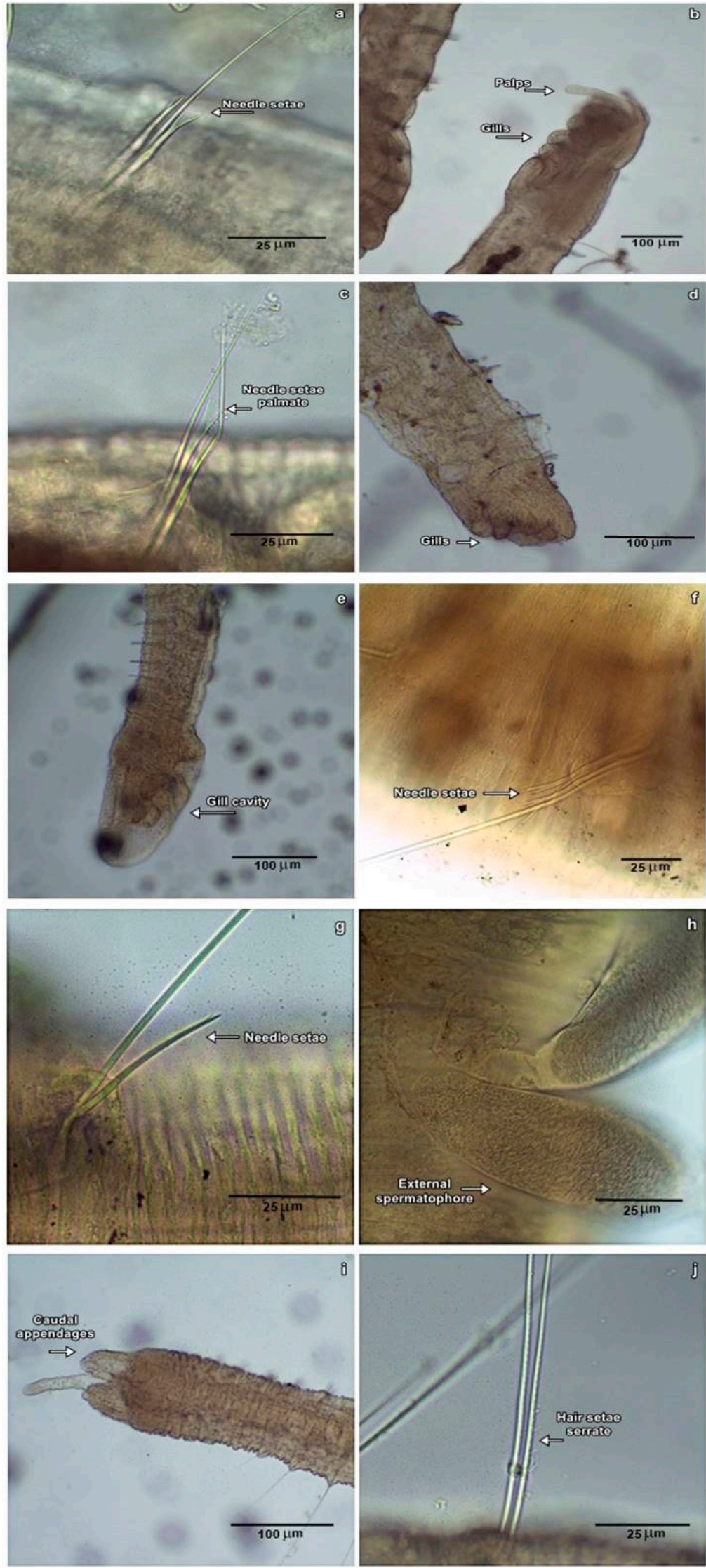

Figure 2. a: Needle setae of Allonais inaequalis; b: Gill cavity of Aulophorus furcatus; c: Needle setae palmate of Aulophorus costatus; d: Gills of Dero digitata; e: Gills of Dero nivea; f: Needle setae of Pristina synclites; $\mathbf{g}$ : Needle setae of Pristina menoni; $\mathbf{h}$ : External spermatophore of Bothrioneurum sp.; i: Caudal appendages of Opistocysta funiculus; $\mathbf{j}$ : Hair setae serrate of Opistocysta funiculus. 
Grande do Sul. It also frequently lives in association with other organisms such as Nymphaea (Marcus, 1944), gastropods (Gorni \& Alves, 2006), macrophytes (Montanholi-Martins \& Takeda, 2001) and also to decomposing macrophyte leaves (Martins et al. 2011). It has been already detected in floodplain habitats (Ragonha \& Takeda, 2014), in streams of preserved areas (Rodrigues et al. 2013) and in irrigated rice fields (Stenert et al. 2012).

\section{Aulophorus costatus Du Bois-Reymond Marcus, 1944 (Figure 2c)}

Its main characteristic is the palmate dorsal needle seta and gill cavity with two pairs of gills (Brinkhurst \& Marchese, 1989). Registration in Brazil has already occurred in the States of Amazonas and Pará, as well as in São Paulo, in association with other organisms such as macrophytes (Alves \& Gorni, 2007) and sponge specimens (Gorni \& Alves, 2008a).

\section{Dero digitata (O. F. Müller, 1773) (Figure 2d)}

In Brazil, this species has been registered in the State of São Paulo, in association with gastropods (Gorni \& Alves, 2006) and macrophytes (Alves \& Gorni, 2007), in reservoirs (Pamplin et al. 2005) and in urban streams (Alves \& Lucca, 2000). In the Amazon region, it has been registered in many rivers in the State of Pará, such as Tapajós River, Cururu River, Acara River, Cupari River, Juruena River and São Samuel River (Marcus 1942, Marcus, 1944, Du Bois-Reymond Marcus, 1947, 1949a, 1949b). It has also occurred in areas of rice fields in Rio Grande do Sul (Stenert et al. 2012).

\section{Dero nivea Aiyer 1930 (Figure 2e)}

This species is cosmopolitan and is mainly characterized by its prolonged gill cavity (Brinkhurst \& Marchese, 1989). Its incidence in Brazil is more significant in the State of São Paulo, but has also been recorded in Rio Grande do Sul. Like other species of Oligochaeta, it can live in association with other organisms, but is especially found on aquatic vegetation (Correia \& Trivinho-Strixino, 1998, Trivinho-Strixino et al. 2000, Alves \& Gorni, 2007).

\section{Pristina synclites Stephenson, 1925 (Figure 2f)}

The records of this species occurrence are in the State of São Paulo, where it was found in urban streams with low concentration of dissolved oxygen (Alves et al. 2006) and in organically enriched reservoirs (Fusari \& Fonseca-Gessner, 2006).

\section{Pristina menoni (Aiyer, 1929) (Figure 2g)}

Species with records only in São Paulo and Paraná. It has been recorded that it associates with bryophytes (Gorni \& Alves, 2007). It has also been found in urban stream waters in São Paulo (Alves et al. 2006) and in the Ivinhema River in Paraná (Montanholi-Martins and Takeda, 2001).

\section{Bothrioneurum sp. (Figure 2h)}

This genus is mainly characterized by the presence of a sensitive organ in the prostomium and the presence of an external spermatophore (Brinkhurst \& Marchese, 1989). Its occurrence has been cataloged in the States of São Paulo, Minas Gerais, Amazonas, Pará and Rio Grande do Sul. It also occurs mainly in the sediments of degraded sites (Alves \& Lucca, 2000; Suriani et al. 2007) and in the streams of preserved areas (Rodrigues et al. 2013). In the south of the country, it has been collected in rice fields (Stenert et al. 2012). In the Amazon region, it was found in Pará, near the County of Belterra, by Marcus (1942) and Du Boys-Reymond Marcus (1947, 1949a and 1949b) and in Central Amazon by Irmler (1989) and Collado \& Schmelz (2000; 2001).

Opistocysta serrata Harman, 1970 (Figure 2i, j)

Serrate hair seta, the presence of proboscis and three (one median and two lateral) caudal appendages (Brinkhurst \& Marchese, 1989) characterize this species. In Brazil it was collected only in the States of Paraná (Montanholi-Martins \& Takeda, 2001) and Mato Grosso do Sul (Takeda et al., 2000).

\section{Discussion}

This study showed the occurrence of 12 taxa, representing approximately $13.95 \%$ of 86 species registered in Brazil (Christoffersen, 2007). In addition, this was the first registration of some species, such as Allonais inaequalis, Aulophorus furcatus, Dero nivea, Pristina synclites, Pristina menoni and Opistocysta serrata, in the Brazilian Amazon region. According to Christoffersen (2010) the catalogued oligochaetes from South America represent only a fraction of their true diversity, which emphasizes the need for more studies that contemplate species inventory in neotropical regions. Most of the global biodiversity data still comes from temperate regions and refer mainly to important and economically valuable taxa. These shortfalls in biodiversity information need to be recognized and quantified for more accurate conservation assessments and actions (Hortal et al. 2015).

In the aquatic community of Oligochaeta, the Naididae family stands out as the most abundant and diverse, consisting of eight subfamilies and comprising about $50 \%$ of the described species on the planet (Rodriguez \& Reynoldson, 2011). Moreover, according to Martin (1996) Naididae is a cosmopolitan family, which is very common in lakes. In this study, this family was the most abundant (95.08\%), mainly represented by the Pristininae subfamily (85.68\%). Some species are periphytic naidids (Pristina), some have gills and respiratory appendages that allow inhabiting systems where oxygen is a limiting factor (Dero, Aulophorus) and others are more often found in sediment (Tubificinae, Bothrioneurum) (Martin, 1996).

From a regional perspective, the State of São Paulo has the highest species richness, with 75 species recorded (Gorni et al. 2015), but little is known about these species in other Brazilian States, which reinforces the importance of studies that seek to verify the occurrence of Oligochaeta in other places. Only recent inventories conducted in States, such as Minas Gerais (Rodrigues et al. 2013) and Rio Grande do Sul (Stenert et al. 2012) have started to change this scenario.

The results of this research will contribute to increase knowledge on Oligochaeta in tropical ecosystems, since some species were reported for the first time in the Western Brazilian Amazon. In this context, it is important to promote other biodiversity studies in areas with difficult access, because according to Hortal et al. (2007) species inventories are more frequent in places that offer more research infrastructure and logistics.

\section{Acknowledgements}

The authors thank the Coordenação de Aperfeiçoamento de Pessoal de Nível Superior (CAPES) for financial support and Instituto Chico Mendes de Conservação da Biodiversidade (ICMBio) for collection assistance, especially to the coordinator of the Reserve, Christiano Andrey Souza do Vale.

\section{References}

AGOstinHO, A. A., THOMAZ, S. M., \& GOMES, L. C. 2005. Conservação da biodiversidade em águas continentais do Brasil. Megadiversidade, 1(1), 70-78.

ALMEIDA, F. F. \& MELO, S. 2009 Considerações limnológicas sobre um lago da planície de inundação amazônica (Lago Catalão-Estado do Amazonas, Brasil). Acta Scient. Biol. Scien. 31(4) 387-395.

ALVES, R.G. \& GORNI, G. R. 2007. Naididae species (Oligochaeta) associated with submersed aquatic macrophytes in two reservoirs (São Paulo, Brazil). Acta Limnol. Bras. 19(4):407-413.

ALVES, R.G.A., MARCHESE, M.R. \& MARTINS, R.T. 2008. Oligochaeta (Annelida: Clitellata) em córregos de baixa ordem do Parque Estadual de Campos do Jordão (São Paulo - Brasil). Biota Neotrop. 8(4) 161-165. http:// www.biotaneotropica.org.br/v8n4/en/abstract?inventory+bn01608042008

ALVES, R.G \& LUCCA, J.V. 2000. Oligochaeta (Annelida: Clitellata) como indicador de poluição orgânica em dois córregos pertencentes à Bacia do Ribeirão do Ouro - Araraquara (São Paulo-Brasil). Braz. J. of Ecol. 4(1-2) 112-117. 
ALVES, R.G., MARCHESE, M.R. \& ESCARPINATI, S.C. 2006. Oligochaeta (Annelida, Clitellata) in lotic environments in the state of São Paulo, Brazil. Iheringia, Zool. 96(4) 431-435.

AVIZ, D., CARVALHO, I. L. R. \& ROSA FILHO, J. S. 2011. Spatial and temporal changes in macrobenthic communities in the Amazon coastal zone (Guajara Estuary, Brazil) caused by discharge of urban effluents. Sci. Mar. 76(2) 381-390.

BRINKURST, R.O \& MARCHESE, M.R. 1989. Guia para la identificación de oligoquetos acuáticos continentales de Sud y Centroamerica. Santa Fé: Asociación de ciencias naturales del litoral.

CARVAJAL, J. J., MONCADA, L. I., RODRÍGUEZ, M. H., PÉREZ, L. D. P., \& OLANO, V. A. 2009. Caracterización preliminar de los sitios de cría de Aedes (Stegomyia) albopictus (Skuse, 1894) (Diptera: Culicidae) en el municipio de Leticia, Amazonas, Colombia. Biomédica, 29(3), 413-423.

CHAPMAN, P. M. 2001. Utility and relevance of aquatic oligochaetes in ecological risk assessment. Hydrobiologia, 463(1) 149-169.

CHRISTOFFERSEN, M.L. 2007. A catalogue of aquatic microdrile oligochaetes (Annelida: Clitellata) from South America. Acta Hydrobiol. Sin. 31(1) 59-86.

CHRISTOFFERSEN, M.L. 2010. Continental biodiversity of south American oligochaetes: the importance of inventories. Acta Zoo. Mex. 2(1) 35-46.

CLETO-FILHO, S.E.N. \& WALKER, I. 2001. Efeitos da ocupação urbana sobre a macrofauna de invertebrados aquáticos de um igarapé da cidade de Manaus - AM Amazônia Central. Acta Amazon. 31(4) 69-89.

COLLADO, R. \& SCHMELZ, R. M. 2001. Descriptions of three Pristina species (Naididae, Clitellata) from Amazonian forest soils, including P. marcusi sp. nov. Hydrobiologia. 463(1) 1-11.

COLLADO, R. \& SCHMELZ, R. M. 2000. Pedonais crassifaucis n.gen., n.sp (Naididae) and Bothrioneurum righii n.sp. (Tubificidae), two new tropical soil-dwelling species of "aquatic" oligochaetes (Clitellata, Annelida) from Central Amazonia. Amazoniana, 16(1) 223-235.

CORBI, J.J., GORNI, G.R. \& CORREA, R.C. 2015. An evaluation of Allonais inaequalis Stephenson, 1911 (Oligochaeta: Naididae) as a toxicity test organism. Ecotoxicol. Environ. Contam. 10(1) 7-11.

CORBI, J.J., JANCSO, M.A., TRIVINHO-STRIXINO, S. \& FRAGOSO, E.N. 2004. Occurence of Oligochaeta living on larvae of Odonata from Ipeúna (São Paulo state, Brazil). Biota neotrop. 4(2) 1-3 http://dx.doi.org/10.1590/167606032015006314

CORREIA, L.C.S. \& TRIVINHO-STRIXINO, S. 1998. Macroinvertebrados da Rizosfera de Scirpus cubensis na lagoa do Infernão (Estação Ecológica de Jataí - SP): Estrutura e função. Acta Limnol. Bras. 10(1) 37-47.

DOCILE, T., ROSA, D. C., FIGUEIRÓ, R. \& NESSIMIAN, J. 2016. Urbanisation alters the flow of energy through stream food webs. Insect Conserv. Divers. 9(1), 416-426.

DU BOIS-REYMOND MARCUS, E. 1947. Naidids and tubificids from Brazil. Com. Zool. del Mus. Montevideo. 44(2) 1-20.

DU BOIS-REYMOND MARCUS, E. 1949a. Further notes on naidids and tubificids from Brazil. Com. Zool. del Mus. Montevideo. 51(3) 1-15.

DU BOIS-REYMOND MARCUS, E. 1949b. A new tubificid from the Bay of Montevideo. Com. Zool. del Mus. Montevideo. 56(3) 1-6.

FUSARI, L.M. \& FONSECA-GESSNER, A.A. 2006. Environmental assessment of two small reservoirs in southeastern Brazil, using macroinvertebrate community metrics. Acta Limnol. Bras. 18(1) 89-99.

GORNI, G. R. \& ALVES, R.G. 2006. Naididae (Annelida, Oligochaeta) associated with Pomacea bridgesii (Reeve) (Gastropoda, Ampullaridae). Rev. Bras. Zool. 23(4): 1059-1061.

GORNI, G. R. \& ALVES, R.G. 2007. Naididae (Annelida, Oligochaeta) associated with briophytes in Brotas, State of São Paulo, Brazil. Rev. Bras. Zool. 24(.2): 518-519.

GORNI, G. R. \& ALVES, R.G. 2008a. Naididae species (Annelida: Oligochaeta) associated with the sponge Metania spinata (Carter, 1881) (Porifera: Metaniidae) from a southeastern reservoir. Acta Limnol. Bras. 20(3) 261-263.

GORNI, G.R. \& ALVES, R.G. 2008b. Oligochaeta (Annelida: Clitellata) in headwater streams of the Parque Estadual de Campos do Jordão (São Paulo - Brazil). Biota Neotrop. 8(4): 161-165. http://www.biotaneotropica.org.br/v8n4/en/abstract?i nventory+bn01608042008.
GORNI, G. R., PEIRO, D. F. \& SANCHES, N. 2015. Aquatic Oligochaeta (Annelida: Clitellata) from State of São Paulo, Brazil: Diversity and Ocurrence review. Biota Neotrop. 15(1) 1-8. http://dx.doi.org/10.1590/1676-06032015006314.

HORTAL, J., DE BELLO, F., DINIZ-FILHO, J. A. F., LEWINSOHN, T. M., LOBO, J. M., \& LADLE, R. J. 2015. Seven shortfalls that beset large-scale knowledge of biodiversity. Annu. Rev. Ecol. Evol. Syst. 46, 523-549.

IRMLER, U. 1989. Population-ecology and migration of Dero multibranchiata Stieren, 1892 (Naididae, Oligochaeta) in the central Amazon inundtion forest. Amazoniana, v. 11(1) 31-52.

JUNK, W. J. 1997. General aspects of floodplain ecology with special reference to Amazonian floodplains. In The Central Amazon Floodplain (pp. 3-20). Springer Berlin Heidelberg.

LEWINSOHN, T. M., \& PRADO, P. I. 2005. How many species are there in Brazil? Conserv. Biol, 19(3), 619-624.

LOPES, A., PAULA, J. D'ARC., MARDEGAN, F., HAMADA, N. \& PIEDADE, M.T.F. 2011. Influência do habitat na estrutura da comunidade de macroinvertebrados aquáticos associados às raízes de Eichhornia crassipes na região do Lago Catalão, Amazonas, Brasil. Acta Amazon. 41(4) 493-502.

MAGURRAN, A. E. 2011. Medindo a diversidade biológica. Editora UFPR: Paraná.

MAITLAND, P. S. 1979. The distribution of zoobenthos and sediments in Loch Leven, Kinross, Scotland. Archiv fur Hydrobiologie, 85, 98-125.

MARCUS, E. 1942. Sôbre algumas Tubificidae do Brasil. Bol. Fac. Fil. Ci. Letr Univ. S. Paulo. 25(6):153-228.

MARCUS, E. 1943. Sobre Naididae do Brasil. Bol. Fac. Fil. Ci. Letr. Univ. S. Paulo. 32(7):3-247.

MARCUS, E. 1944. Sobre Oligochaeta límnicos do Brasil. Bol. Fac. Fil. Ci. Letr Univ. S. Paulo. 43(8):5-135

MARTIN, P. 1996. Oligochaeta and Aphanoneura in ancient lakes: a review. Hydrobiologia. 334(1): 63-72

MARTINS, R.T., SILVEIRA, L.S. \& ALVES, R.G. 2011. Colonization by oligochaetes (Annelida: Clitellata) in decomposing leaves of Eichhornia azurea (SW.) Kunth (Pontederiaceae) in a neotropical lentic system. Ann. Limnol. 47(1) 339-346.

MARTINEZ, J. M., \& LE TOAN, T. 2007. Mapping of flood dynamics and spatial distribution of vegetation in the Amazon floodplain using multitemporal SAR data. Remote sensing of Environment, 108(3), 209-223.

MONTANHOLI-MARTINS, M.C. \& TAKEDA, A.M. 2001 Spatial and temporal variations of oligochaetes of the Ivinhema River and Patos Lake in the Upper Paraná River Basin, Brazil. Hydrobiologia. 463(1-3) 197- 205.

ODA, F. H., PETSCH, D. K., RAGONHA, F. H., BATISTA, V. G., TAKEDA, A. M. \& TAKEMOTO, R. M. 2015. Dero (Allodero) lutzi Michaelsen, 1926 (Oligochaeta: Naididae) associated with Scinax fuscovarius (Lutz, 1925) (Anura: Hylidae) from Semi-deciduous Atlantic Rain Forest, southern Brazil Braz. J. Biol. 75(1) 86-90

PAMPLIN, P.A.Z., ROCHA, O. \& MARCHESE, M. 2005. Riqueza de espécies de Oligochaeta (Anellida, Clitellata) em duas represas do Rio Tietê (São Paulo). Biota Neotrop. 5(1) 1-8 http://dx.doi.org/10.1590/S1676-06032005000100007.

RAGONHA, F.H. \& TAKEDA, A. M. 2014. Does richness of Oligochaeta (Annelida) follows a linear distribution with habitat structural heterogenety in aquatic sediments? Jour. Limnol. 73(1) 146-156.

RIGHI, G. 1984. Manual de identificação de invertebrados límnicos do Brasil $\mathrm{CNpq} /$ Coordenação Editorial.

RODRIGUES, L. F. T., LEITE, F. S. \& ALVES, R. G. 2013. Inventory and distribution of Oligochaeta (Annelida: Clitellata) in first-order streams in preserved áreas of the state of Minas Gerais, Brazil. Biota Neotrop. 13(1) 245-254.

RODRIGUEZ, P. \& REYNOLDSON, T.B. 2011. The Pollution Biology of Aquatic Oligochaetes. Ed. Springer Science.

STENERT; C., MALTCHIK, L. \& ROCHA, O. 2012. Diversidade de invertebrados aquáticos em arrozais no Sul do Brasil. Neotrop. Biol. Conserv. 7(1) 67-77.

SURIANI, A.L., FRANÇA, R.S., PAMPLIN, P.A.Z., MARCHESE, M., LUCCA, J.V. \& ROCHA, O. 2007. Species richness and distribution of oligochaetes in six reservoirs on Middle and Low Tietê River (SP, Brazil). Acta Limnol. Bras. 19(4) 15-426.

SURIANI-AFFONSO, A.L., FRANÇA, R.S., MARCHESE, M. \& ROCHA, O. 2011. Environmental factors and benthic Oligochaeta (Annelida, Clitellata) assemblages in a stretch of the Upper São Francisco River (Minas Gerais State, Brazil). Braz. J. Biol. 71(2) 437-446. 
TAKEDA, A. M., PEREIRA, M. C. F. \& BARBOSA, F. A. R. 2000. Zoobenthos survey of the Pantanal, Mato Grosso do Sul, Brasil. Bull. Biol. Assess. Enginee.

TIMM, T. 1999. Distribution of freshwater oligochaetes in the west and east coastal regions of North Pacific Ocean. Hydrobiologia. 406(1) 67-81.

TRIVINHO-STRIXINO, S., CORREIA, L.C.S. \& SONODA, K. 2000. Phytophilous Chironomidae (Diptera) and other macroinvertebrates in the ox-bow Infernão Lake (Jataí Ecological Station, Luiz Antônio, SP, Brazil). Rev. Bras. Biol. $60(3) 527-535$.
TURCOTTE, P., \& HARPER, P. P. 1982. The macro-invertebrate fauna of a small Andean stream. Freshw. Biol. 12(5), 411-419.

Received: 20/07/2016

Revised: 30/12/2016

Accepted: 02/01/2017

Published online: 16/01/2017 